\title{
Sanctions Imposed by Courts on Attorneys Who Abuse the Judicial Process
}

The increasing concern over the congestion of the judicial system has produced little discussion focusing on the critical role that attorneys have played in the tremendous growth of litigation. Lawyers contribute to the overburdening of the courts by abusing the judicial process in a number of ways-by failing to appear at trials on time, by failing to answer depositions or interrogatories, by making frivolous objections at trial, and by instituting meritless actions. This comment will examine several of the sanctions available to courts faced with attorneys who abuse the judicial process. Contempt, the sanction most frequently utilized against attorneys, suffers from certain deficiencies that often limit its effectiveness in regulating attorney misconduct. This comment suggests that a variety of virtually ignored sanctions is available to courts: section 1927 of Title 28 of the United States Code; rule 37 of the Federal Rules of Civil Procedure; and the inherent power of courts to promulgate rules regulating attorneys' conduct. Finally, two nonjudicial sanctions-actions brought by private parties and bar disciplinary proceedings-are briefly examined.

\section{The Contempt Sanction}

Punishing an individual for disrupting or obstructing the judicial process has traditionally been viewed as a power inherent in all courts, necessary to preserve order in judicial proceedings and to ensure the fair administration of justice. ${ }^{1}$ This inherent power has been codified for the federal courts, beginning with the Judiciary Act of $1789^{2}$ and continuing through the present contempt sanction, section 401 of Title $18 .^{3}$ This statute is supplemented by rule 42 of

I In Ex parte Robinson, 86 U.S. (19 Wall.) 505, 510 (1873), the Court stated:

The power to punish for contempts is inherent in all courts; its existence is essential to the preservation of order in judicial proceedings, and to the enforcement of the judgments, orders, and writs of the courts, and consequently to the due administration of justice. The moment the courts of the United States were called into existence and invested with jurisdiction over any subject, they became possessed of this power.

For a history of the development of the contempt power, see Comment, The Application of Criminal Contempt Procedures to Attorneys, 64 J. CRIM. L. \& C. 300 (1973). A thorough discussion can be found in R. Goldfarb, THE ConTEMPT Power (1963).

2 The Judiciary Act of 1789 provided that all federal courts had the power "to punish . . . by fine or imprisonment, at the discretion of said courts, all contempts of authority in any cause or hearing before same." Judiciary Act of 1789, ch. $20, \S 17,1$ Stat. 83.

" 18 U.S.C. $\$ 401$ (1970) provides: 
the Federal Rules of Criminal Procedure, which provides procedures for both summary and nonsummary contempts. ${ }^{4}$ In addition, most states have contempt statutes governing litigation in state courts. ${ }^{5}$ Despite its universality, however, the contempt power is limited in ways that make it unsatisfactory as an effective sanction against attorneys.

\section{A. The Intent Requirement}

The primary limit on a court's power to punish attorneys for contempt is the well-established principle that a contemnor must have "willfully disregarded" the authority of the court. Such a restrictive mens rea requirement often makes it difficult for the contempt power to deal effectively with attorneys who abuse the judicial process. In Sykes $v$. United States, ${ }^{7}$ for example, an attorney had failed to appear at a scheduled trial because of his confusion over the date set for the commencement of the trial. The trial court found the failure to appear to be negligent and fined him for contempt. The court of appeals, however, reversed the contempt conviction, stating that "an essential element of ... [the] offense is

A court of the United States shall have power to punish by fine or imprisonment, at its discretion, such contempt of its authority, and none other, as-

(1) Misbehavior of any person in its presence or so near thereto as to obstruct the administration of justice;

(2) Misbehavior of any of its officers in their official transactions;

(3) Disobedience or resistance to its lawful writ, process, order, rule, decree, or command.

' FED. R. CRIM. P. 42 provides:

(a) Summary Disposition. A criminal contempt may be punished summarily if the judge certifies that he saw or heard the conduct constituting the contempt and that it was committed in the actual presence of the court. The order of contempt shall recite the facts and shall be signed by the judge and entered of record.

(b) Disposition upon Notice and Hearing. A criminal contempt except as provided in subdivision (a) of this rule shall be prosecuted on notice. The notice shall state the time and place of hearing, allowing a reasonable time for the preparation of the defense, and shall state the essential facts constituting the criminal contempt charged and de. scribe it as such. The notice shall be given orally by the judge in open court in the presence of the defendant or, on application of the United States attorney or of an attorney appointed by the court for that purpose, by an order to show cause or an order of arrest. The defendant is entitled to a trial by jury in any case in which an act of Congress so provides. He is entitled to admission to bail as provided in these rules. If the contempt charged involves disrespect to or criticism of a judge, that judge is disqualified from presiding at the trial or hearing except with the defendant's consent. Upon a verdict or finding of guilt the court shall enter an order fixing the punishment.

5 E.g., N.Y. Penal Law § 215.50 (McKinney 1975); Cal. Crv. Proc. Code $\$ 1209$ (West 1972).

6 See, e.g., Taylor v. District Court, 434 P.2d 679, 681 (Alas. 1967).

7444 F.2d 928 (D.C. Cir. 1971). 
an intent, either specific or general, to commit it [citing cases]. By definition, contempt is a 'wilful disregard or disobedience of a public authority." "The court found that the attorney in Sykes could not be held liable since "his failure to appear was not by design but resulted from a lapse of memory, preoccupation with another case, and confusion as to dates."

Several courts have circumvented this strict mens rea requirement by relying on an inherent power to impose court costs on attorneys. As one court has stated, "[T] court to manage its affairs necessarily includes the authority to impose reasonable and appropriate sanctions upon errant lawyers practicing before it."10 The New York state courts have systematically used the power to regulate court procedure as a basis for sanctioning attorneys who are negligent in their duties to their clients and the court. In Moran v. Rynar, ${ }^{11}$ for example, the defendant moved to dismiss the suit after the plaintiff had failed to file a document within the required time period. The court, noting that the plaintiff's failure to file the document was entirely due to the attorney's neglect, declined to dismiss the action, but ordered the plaintiff's attorney personally to pay the cost of the delay to the defendant. The court rationalized the fine by stating that since "an attorney's neglect or inadvertent error should not deprive his client of his day in court . . . it is proper to save the action for the client, while imposing upon the attorney, personally, a penalty for his neglect." ${ }^{12}$ Similarly, in Kahn v. Stamp, ${ }^{13}$ the defendant's attorney apparently overlooked the existence of an outstanding preclusion order and failed to file answers to interrogatories. The New York State Supreme Court ruled that the proper sanction was not a default judgment, and instead imposed a fine directly on the negligent attorney.

"Id. at 930 .

- Id. See also In re Adams, 505 F.2d 949 (5th Cir. 1974); In re Farquhar, 492 F.2d 561 (D.C. Cir. 1973); McMullin v. Sulgrove, 459 S.W.2d 383 (Mo. 1970). A few other cases have implicitly rejected a strict mens rea requirement. In United States v. Ford, 9 F.2d 990, 992 (D. Mont. 1925), for example, an attorney filed a bill of exceptions that contained fifty-five exceptions to rulings of the court, twenty-seven of which were completely fictitious. Although the court appeared to accept the attorney's explanation that the errors were due to his negligence, it stated: "In contempt, as in many varieties of crime, not always needs there be an evil quality of the mind. It suffices if the latter's equivalent appears in forgetfulness, neglect, or failure of or indifference to duty or consequences."

10 Flaska v. Little River Marine Constr. Co., 389 F.2d 885, 888 (5th Cir. 1968).

" 39 App. Div. 2d 718, 332 N.Y.S.2d 138 (1972).

${ }_{12}$ Id. at $719 ; 332$ N.Y.S.2d at 138.

13 52 App. Div. 2d 748, 382 N.Y.S.2d 199 (1976). 
Moran and Kahn are just two of the many recent state court cases in New York that have imposed costs on attorneys personally for negligent behavior. ${ }^{14}$ However, most jurisdictions do not recognize an inherent power other than the contempt sanction that would allow a court to impose costs on negligent attorneys. ${ }^{15}$ The contempt power and the power to levy costs both originate in a court's inherent power to control its proceedings. The only material difference between contempt and the inherent power to impose costs is that a contempt fine is ordinarily paid directly to the court, while the fines imposed in the New York cases levying costs on negligent attorneys were consistently paid to the opposing litigant. The New York courts have, in effect, evaded the strict mens rea requirement of contempt by relying on the same underlying power to impose a sanction interpreted to encompass negligent misbehavior. This evasion may explain the reluctance of the majority of courts to impose costs as a sanction against attorneys.

\section{B. The Direct-Indirect Distinction}

A second problem with the contempt sanction is the traditional distinction between direct and indirect contempt. While a direct contempt can be punished summarily, an indirect contempt cannot be punished without a full trial. Under state $^{16}$ and federal ${ }^{17}$ statutes, the determination of whether a contempt is direct or indirect turns on whether it is committed in the "immediate view and presence of the court." The clearest illustration of a direct contempt is contumacious conduct committed in open court, such as offensive language directed at the court during a trial. ${ }^{18}$ An indirect contempt is

"See, e.g., Farm Automation Corp. v. Senter, 52 App. Div. 2d 574, 382 N.Y.S.2d 525 (1976); Bellavia v. Allied Elec. Motor Serv., 46 App. Div. 2d 807, 361 N.Y.S.2d 193 (1974); Gallante v. Solon Holding Corp., 46 App. Div. 2d 636, 360 N.Y.S.2d 252 (1974); Livingston v. Kaufman, 44 App. Div. 2d 668, 354 N.Y.S.2d 440 (1974); Moscatiello v. Savarese, 42 App. Div. 2d 519, 344 N.Y.S.2d 285 (1973); Schwartz v. Cuozzo, 40 App. Div. 2d 726, 337 N.Y.S.2d 11 (1972); Williams v. Jewish Hosp. of Brooklyn, 40 App. Div. 2d 532, 334 N.Y.S.2d 227 (1972).

15 See, e.g., Stayner v. Bruce, 123 Ind. App. 467, 110 N.E.2d 511 (1953) ("the right to recover costs and liability for the payment thereof are matters entirely for the legislature [citing cases], and courts have no inherent power in connection therewith").

16 The New York statute is typical:

Where the offense is committed in the immediate view and presence of the court, or of the judge or referee, upon a trial or hearing, it may be punished summarily. For that purpose, an order must be made by the court ... stating the facts which constitute the offense and which bring the case within the provisions of this section, and plainly and specifically prescribing the punishment to be inflicted therefor.

N.Y. JudiciarY LaW $§ 755$ (McKinney 1968).

"See note 4 supra.

is See, e.g., Commonwealth v. Langnes, 434 Pa. 478, 255 A.2d 131 (1969); Taylor v. Gladden, 232 Or. 599, 377 P.2d 14 (1962). 
the disobedience of a judicial order to be performed outside the court, such as a party's failure to comply with an injunction. ${ }^{19}$ In many situations, however, determining whether an attorney's misconduct constitutes direct or indirect contempt is nearly impossible. In the California case of Chula $v$. Superior Court, ${ }^{20}$ an attorney (Chula) asked an associate to appear in court for him. When the associate arrived twenty minutes late, the court found Chula to be in contempt and punished him summarily since his conduct occurred in the "immediate view and presence of the court." Roselle $v$. State ${ }^{22}$ an appellate court held that an attorney who was ten minutes late for the start of a court session had committed an indirect contempt since his activities were "not entirely in the presence nor observed by the trial court."23

The artificiality of the direct-indirect distinction, and the inflexibility of the mens rea requirement, suggest that the contempt sanction is inadequate to regulate the full gamut of attorney misconduct. Several alternative sanctions may be more responsive to judicial needs.

\section{Section 1927}

A sanction with great promise as an effective measure against attorney misconduct in federal courts is a little used federal statute, section 1927 of Title $28 .{ }^{24}$ This statute, first enacted in 1813, states:

Any attorney or other person admitted to conduct cases in any court of the United States or any Territory thereof who so mul. tiplies the proceedings in any case as to increase costs unreasonably and vexatiously may be required by the court to satisfy personally such excess costs.

Modified in minor aspects since its enactment, ${ }^{25}$ the statute requires that three essential elements be satisfied as a condition of liability: a multiplication of proceedings by an attorney, by conduct

" See, e.g., Upper Lakes Shipping, Ltd. v. Seafarers' Int'l Union, 22 Wis. 2d 7, 125 N.W.2d 324 (1963).

20 57 Cal. 2d 199, 368 P.2d 107, 18 Cal. Rptr. 507 (1962).

21 Id. at 203; accord, Lyons v. Superior Court, 43 Cal.2d 755, 278 P.2d 681, cert. denied, 350 U.S. 876 (1955).

22509 P.2d 486 (Okla. Crim. App. 1973).

2 Id. at 488; accord, Jessup v. Clark, 490 P.2d 1068 (3d Cir. 1973); Klein v. United States, 151 F.2d 286 (D.C. Cir. 1945). The Supreme Court has indicated that the rigid direct-indirect test may be giving way to a more flexible standard. See Harris v. United States, 382 U.S. 162 (1965); Panico v. United States, 375 U.S. 29 (1963).

2828 U.S.C. \& 1927 (1970).

${ }^{25}$ Ch. 14, $\$ 3,3$ Stat. 21 (1813). 
that can be characterized as "unreasonable and vexatious," resulting in an increase in the cost of the proceedings. ${ }^{26}$

\section{A. The Multiplication of Proceedings Requirement}

The few courts that have invoked section 1927 provide inconsistent determinations of what constitutes a multiplication of proceedings within the meaning of the statute. In Weiss $v$. United States, ${ }^{27}$ for example, the plaintiff had failed in an initial attempt to recover life insurance proceeds, and instituted two additional actions that varied only slightly from her original action. The plaintiff then offered a third version of her previous complaints which the court noted was "so slight a variation as to be perceived only with difficulty." 28 Nevertheless, the court refused to find that she was "multiply[ing] the proceedings," warning that a further attempt to reopen this "hopeless"29 case would subject the plaintiff"s attorney to costs under section 1927. Kiefel v. Las Vegas Hacienda, Inc. ${ }^{30}$ is an example of attorney misconduct found to meet the multiplication of proceedings requirement. The defendant's attorney had deliberately changed an answer in a deposition that he was reading to the jury from "incorrect" to "correct," had examined a witness on an exhibit that had not been offered in evidence, and had repeatedly made meritless objections..$^{31}$ In response to these actions, and in light of the attorney's "history of misconduct [that] is well documented in the prior opinions of this court," 32 the trial court levied costs on the attorney personally under section 1927.

Still other courts have held attorneys liable under section 1927 for relatively mild misconduct. In Bardin $v$. Mondon, ${ }^{33}$ the plaintiff's counsel, who had previously stated that he was ready to go to trial, requested a continuance on the morning of the trial on the

${ }^{26}$ Section 1927 is silent as to how it can be invoked. Compare United States v. Ross, 535 F.2d 346 (6th Cir. 1976) ( $\$ 1927$ invoked sua sponte by the lower court), with 1507 Corp. v. Henderson, 447 F.2d 540 (7th Cir. 1971) ( $\$ 1927$ invoked by a motion by a party). The statute also fails to specify to whom costs should be paid. Compare Kiefel v. Las Vegas Hacienda, Inc., 404 F.2d 1163 (7th Cir. 1968) (costs imposed under $§ 1927$ paid to the opposing party), cert. denied, 395 U.S. 908 (1969), with Bardin v. Mondon, 298 F.2d 235 (2d Cir. 1961) (costs imposed under $\S 1927$ paid directly to the court).

${ }_{27} 227$ F.2d 72 (2d Cir. 1955), cert. denied, 350 U.S. 936 (1956).

${ }^{2 x} I d$. at 73.

${ }^{29} \mathrm{Id}$.

so 404 F.2d 1163 (7th Cir. 1968).

II For a detailed discussion of the misbehavior in Kiefel, see $404 \mathrm{~F} .2 \mathrm{~d} 1163,1164-70$ (7th Cir. 1968), cert. denied, 395 U.S. 908 (1969).

32 Id. at 1167.

${ }^{33} 298$ F.2d 235 (2d Cir. 1961). 
ground that the attorney he had designated to try the case was ill and unable to proceed. The trial court found this excuse inadequate and dismissed the case with prejudice when the plaintiff was unprepared to proceed. The Second Circuit, however, observing that it was unfair to make the plaintiff suffer for the misconduct of his counsel, agreed to dismiss the case without prejudice if the attorney paid one hundred dollars as costs to the district court under section $1927 . .^{34}$

The approach of the Bardin and Kiefel courts is preferable to the restrictive interpretation of the multiplication of proceedings requirement exemplified by the Weiss opinion. The multiplication of proceedings requirement appears to impose an objective test requiring a court to assess the impact of an attorney's improper conduct on the court's processes. The attorney in Weiss who filed three virtually indistinguishable actions after failing in an initial attempt to recover insurance proceeds clearly multiplied the proceedings; the court gave no reason for stating that four such actions were required to meet the statutory test. Satisfaction of the multiplication of proceedings requirement, however, is not sufficient to establish liability under section 1927; the attorney must also act unreasonably and vexatiously, and increase costs.

\section{B. The Unreasonable and Vexatious Requirement}

Courts have also been inconsistent in applying the statute's unreasonable and vexatious requirement. The majority view, as expressed in the Kiefel case, is that the language "unreasonable and vexatious" imposes a "restrictive standard" 35 that "courts should exercise only in instances of a serious and studied disregard for the orderly processes of justice." 36 It was appropriate to levy costs in Kiefel because the attorney's actions, such as altering an answer to a deposition, were found to be intentional, "involving serious breaches of the Canons of Ethics." 37

34 Similarly, in the recent case of United States v. Ross, 535 F.2d 346 (6th Cir. 1976), an attorney negligently failed to appear at a scheduled trial date and thereby caused the state to bear the expenses of unnecessarily summoning a jury venire of forty-two persons. The court found that the attorney's behavior clearly satisfied the misconduct requirement of $\$ 1927$; only the court's uneasiness about the requisite state of mind and the meaning of "cost" in the statute led it to reverse the trial court's imposition of $\$ 1,027.80$ as costs on the attorney. See also 1507 Corp. v. Henderson, 447 F.2d 540 (7th Cir. 1971).

is 404 F.2d 1163, 1167 (7th Cir. 1968), cert. denied, 395 U.S. 908 (1969).

3s Id.

${ }^{37}$ Id. 
In United States $v$. Ross, ${ }^{38}$ the Sixth Circuit relied upon this narrow interpretation of section 1927 in reversing a district court's application of the statute to an attorney whose behavior demonstrated "complete negligence" 39 but was not "purposeful or malicious." and studied disregard" standard, the Ross court offered two arguments. First, the court stated that the joining of "vexatious" with "unreasonably" in the statute clearly indicated that negligent behavior was insufficient for liability, since the dictionary defined "vexatious" as " "lacking justification and intended to harass." "4i Second, the court looked to the unusual nature of a sanction that imposed costs on an attorney rather than on a litigant, concluding that:

it seems appropriate not to impose this sanction for an unintended inconvenience to the court no matter how annoying it might be. Personal responsibility should, in this instance, flow only from an intentional departure from proper conduct, or, at a minimum, from a reckless disregard of the duty owed by counsel to the court. ${ }^{42}$

Other courts, adopting a somewhat more liberal view, have equated "unreasonably and vexatiously" with "bad faith." 43

The restrictive statutory interpretation offered by the courts is open to question. The statute's language does not limit its application to attorneys who act intentionally or in bad faith. The term "unreasonably" does not import any degree of culpability above negligence; the word is most commonly associated with irrational, unwise, or arbitrary conduct. ${ }^{44}$ The mens rea requirement suggested by the inclusion of "vexatious" in the statute is also unclear. Notwithstanding the dictionary definition relied on in Ross, the term

${ }^{3 x} 535$ F.2d 346 (6th Cir. 1976).

39 Id. at 348.

so Id. at 350 .

"Id. at 349, quoting Webster's ThiRd New International Dictionary (1971).

$12 I d$.

${ }^{13}$ In West Virginia v. Chas. Pfizer \& Co., 440 F.2d 1079, 1092 (2d Cir. 1971), cert. denied, 404 U.S. 871 (1971), a class action brought under the antitrust laws, the court refused to award costs on the ground that the use of $\$ 1927$ was "highly unusual and requires a clear showing of bad faith." A similar "good faith" standard was apparently relied upon in Miles v. Dickson, 387 F.2d 716, 717 (5th Cir. 1967), to deny the imposition of costs. See also Coyne \& Delany Co. v. G.W. Onthank Co., 10 F.R.D. 435, 436 (S.D. Iowa 1950).

" E.g., In re Public Utilities Comm'r of Ore., 268 P.2d 605, 616 Or. 1 (1954); Wisconsin Tel. Co. v. Public Service Comm'n, 232 Wis. 274, 626, 287 N.W. 122, 131 (1939), cert. denied, 309 U.S. 657 (1940). 
"vexatious" can also connote a minimum degree of culpability.45 Vexatious conduct can be defined as conduct that causes annoyance or irritation in the opposing party; a person's conduct should be labeled "vexatious" not in reference to his own state of mind, but based on the effect his conduct has on his opponent. ${ }^{46}$ Thus the statutory language defining the requisite mens rea is ambiguous, and can support either a flexible or strict interpretation.

A strong policy argument can be made that the statute should be applied against attorneys who unnecessarily increase costs even if they display no "reckless disregard" of their duties to the court. As the Second Circuit noted in Motion Pictures Patents Co. $v$. Steiner, " ${ }^{47}$ " $\left.t\right]$ he section permits the court to order that an attorney who has unnecessarily increased the costs shall pay personally

15 See American Herttage Dictionary of the English Language 1426 (1969) (defining vexatious as "causing or creating vexation; annoying, irksome"); RANDOM HouSE DicTIONARY OF THE ENGLISH LANGUAGE 1590 (1967) (defining vexatious as "causing vexation, troublesome, annoying").

"See note 45 supra. This interpretation of vexatious is supported by its use in other contexts. For example, a frequently utilized Missouri statute providing for actions against insurance companies that "vexatiously" refuse to pay claims states:

In any action against any insurance company to recover the amount of any loss under a policy of fire, cyclone, lightning, life, health, accident, employers' liability, burglary, theft, embezzlement, fidelity, indemnity, marine or other insurance, if it appears from the evidence that such company has vexatiously refused to pay such loss, the court or jury may, in addition to the amount thereof and interest, allow the plaintiff damages not to exceed ten per cent on the amount of the loss and a reasonable attorney's fee; and the court shall enter judgment for the aggregate sum found in the verdict (emphasis added).

Mo. ANN. Stat. $\$ 375.420$ (Vernon 1968). The cases interpreting this statute have held that "vexatiously" means unreasonable conduct. See, e.g., Pfingsten v. Franklin Life Ins. Co., 330 S.W.2d 806, 817 (Mo. 1959); Howard v. Aetna Life Ins. Co., 350 Mo. 17, 164 S.W.2d 360 (1942).

The term "vexatious" also appears in subsection $138.19(\mathrm{k})$ of the Illinois Workmen's Compensation Act. This statute states:

In case where [sic] there has been any unreasonable or vexatious delay of payment or intentional underpayment of compensation, or proceedings have been instituted or carried on by the one liable to pay the compensation, which do not present a real controversy, but are merely frivolous or for delay, then the Commission may award compensetion additional to that otherwise payable under this Act equal to $50 \%$ of the amount payable at the time of such award. Failure to pay compensation in accordance with the provisions of section 8 , paragraph (b) of this Act, shall be considered unreasonable delay. ILL. REv. STAT. ch. 48, $\S 138.19(\mathrm{k})(1973)$. The most definitive interpretation of "vexatious" in this context is in Board of Educ. v. Industrial Comm'n, 351 Ill. 128, 184 N.E. 202 (1933), where the Illinois Supreme Court stated that "in determining whether such delay has been unreasonable or vexatious regard must be had to the circumstances attending the delay, the nature of the case and the relief demanded, and also to the question whether the rights of the claimant have been prejudiced by that delay." Id. at 132, 124 N.E. at 204. See also Chicago v. Industrial Comm'n, 63 Ill.2d 99, 345 N.E.2d 477 (1976); People ex rel. Barclay v. West Chicago Park Comm'rs, 308 Ill. App. 602, 32 N.E.2d 323 (1941).

ง7 201 F. 63 (2d Cir. 1912). 
the excess of such costs over the amount which was properly incurred." ${ }^{48}$ Costs can be increased as dramatically by a negligent act as by an intentional act; to apply section 1927 only to nonnegligent acts severely curtails its effectiveness. If an attorney has negligently imposed costs on the judicial system, there is no unfairness in making him accountable.

\section{The Increased Costs Requirement}

The third element that must be present for section 1927 liability is an increase in the costs of the proceeding over those which should properly have been incurred. ${ }^{49}$ In United States $v$. Ross, ${ }^{50}$ the Sixth Circuit interpreted the cost requirement in an opinion reversing the trial court's imposition of the cost of calling a jury on an attorney. The court stated that "[b]ecause $\S 1927$ is penal in nature, we believe that it should be strictly construed, and we agree with the Seventh Circuit's determination that 'costs' should be limited to taxable costs." In a footnote, the Ross court explained this statement:

If the district court's analysis were carried to its logical conclusion, an attorney who caused the proceedings to be extended "unreasonably and vexatiously" could be required to pay the pro rata salaries of the judge, his staff, the U.S. Attorney and marshals, in addition to the expenses for any witnesses called. We do not believe that the statute was meant to include such "costs." 52

Determining the costs that can be recovered under section 1927 can be difficult. One interpretation would be to limit the costs that can be assessed to those incurred by the opposing litigant. While this position has the advantages of certainty and relative ease of administration, it ignores the problem of attorneys whose actions impose unreasonable costs on the judicial system without affecting the opposing litigant. Such costs should also be recoverable if section 1927 is to be an effective deterrent against and remedy for attorney misconduct. If the attorney's actions unnecessarily con-

งx Id. at 64 (interpreting an earlier, almost identical, version of $\S 1927$.

19 See, e.g., In re Realty Assocs. Sec. Corp., 53 F. Supp. 1013, 1014 (E.D.N.Y. 1943), aff'd, 156 F.2d 480 (2d Cir. 1946) ( $\$ 1927$ "merely authorizes the taxing of such excess of costs as arose from unreasonable and vexatious conduct of an attorney ...").

so 535 F.2d 346 (6th Cir. 1976).

5 Id. at 350 .

${ }^{32} \mathrm{Id}$. at 351 . 
sume the time of a judge, jury, United States attorney, or other judicial personnel, the attorney can reasonably be held responsible for the pro rata salaries of these individuals. ${ }^{53}$ However, such an expansion of potential liability under section 1927 may require a clearer manifestation of congressional intent than the statute and its history currently provide.

Even if the increased costs requirement of section 1927 is limited to costs suffered by the opposing litigant, courts could effectively use the statute as a supplement to the contempt sanction with much greater frequency. If the vexatiously and unreasonably requirement is flexibly interpreted, section 1927 would allow courts to impose costs on attorneys who could not be found liable under the rigid mens rea requirement of contempt.

\section{Rule 37 of the Federal Rules of Civil Procedure}

Although it is rarely enforced as a sanction for attorney misconduct, rule 37 of the Federal Rules of Civil Procedure contains several provisions that explicitly permit a court to levy costs against a lawyer. Rule 37, while limited to situations involving pretrial discovery, can provide a useful sanction. Under subdivision (a) of the rule, a motion to compel an answer, a designation, or an inspection may be made in four specified situations. ${ }^{54}$ Whether or not the motion to compel discovery is granted, the court may require the attorney "advising such conduct" in obtaining the order or opposing the motion unless the court finds that the attorney's action was "substantially justified."s6

ss A more liberal interpretation of costs under $\S 1927$ is suggested by the recent case of Acevedo v. Immigration \& Naturalization Serv., 538 F.2d 918 (2d Cir. 1976), where the court imposed double costs on an attorney pursuant to 28 U.S.C. $\$ \S 1912,1927$, and rule 38 of the Federal Rules of Appellate Procedure.

st Section (2) of subdivision (a) states:

(2) Motion. If a deponent fails to answer a question propounded or submitted under Rule 30 or 31 , or a corporation or other entity fails to make a designation under Rule 30 (b) (6) or 31(a), or a party fails to answer an interrogatory submitted under Rule 33, or if a party, in response to a request for inspection submitted under Rule 34, fails to respond that inspection will be permitted as requested or fails to permit inspection as requested, the discovering party may move for an order compelling an answer, or a designation, or an order compelling inspection in accordance with the request.

ss FED. R. Crv. P. 37(a).

st Id. The entire rule states:

(4) Award of Expenses of Motion. If the motion is granted, the court shall, after opportunity for hearing, require the party or deponent whose conduct necessitated the motion or the party or attorney advising such conduct or both of them to pay to the moving party the reasonable expenses incurred in obtaining the order, including attorney's fees, unless the court finds that the opposition to the motion was substantially justified or that other circumstances make an award of expense unjust. 
If a party fails to comply with a court order to permit discovery, including an order made under subsection (a) of rule 37, several alternative sanctions can be invoked under subsection (b). One sanction provided is that:

In lieu of any of the foregoing orders or in addition thereto, the court shall require the party failing to obey the order or the attorney advising him or both to pay the reasonable expenses, including attorney's fees, caused by the failure, unless the court finds that the failure was substantially justified or that other circumstances make an award of expenses unjust. ${ }^{57}$

Similarly, subdivision (d) of the rule provides that if a party fails to attend his own deposition, to serve answers to interrogatories, or to respond to a request for inspection, the court "may make such orders in regard to the failure as are just," 58 including any action authorized in subdivision (b). The court also has the option of imposing reasonable expenses on the party failing to act, or his attorney, unless the court finds that the failure can be "substantially justified." ${ }^{59}$

If the motion is denied, the court shall, after opportunity for hearing, require the moving party or the attorney advising the motion or both of them to pay to the party or deponent who opposed the motion the reasonable expenses incurred in opposing the motion, including attorney's fees, unless the court finds that the making of the motion was substantially justified or that other circumstances make an award of expenses unjust.

If the motion is granted in part and denied in part, the court may apportion the reasonable expenses incurred in relation to the motion among the parties and persons in a just manner.

${ }^{37}$ FED. R. Civ. P. 37(b) (emphasis added).

5* FED. R. Civ. P. 37(d).

s9 Subdivision (d) states in part:

(d) Failure of Party to Attend at Own Deposition or Serve Answers to Interrogatories or Respond to Request for Inspection. If a Party or an Officer, director, or managing agent of a party or a person designated under Rule $30(b)(6)$ or $31(a)$ to testify on behalf of a party fails (1) to appear before the officer who is to take his deposition, after being served with a proper notice, or (2) to serve answers or objections to interrogatories submitted under Rule 33, after proper service of the interrogatories, or (3) to serve a written response to a request for inspection submitted under Rule 34 , after proper service of the request, the court in which the action is pending on motion may make such orders in regard to the failure as are just, and among others it may take any action authorized under paragraphs (A), (B), and (C) of subdivision (b)(2) of this rule. In lieu of any order or in addition thereto, the court shall require the party failing to act or the attorney advising him or both to pay the reasonable expenses, including attorney's fees, caused by the failure, unless the court finds that the failure was substantially justified or that other circumstances make an award of expenses unjust.

Each of the three subdivisions operates by different procedures. Under subdivision (a), a party must initially make a motion asking the court to compel discovery; once such a motion is made the court automatically considers the question of awarding expenses against a party 
Despite these provisions, only a few reported cases apply rule 37 to sanction misbehaving attorneys. The most commonly applied provision is subdivision (a), used when a party unjustifiably refuses to answer questions in an oral deposition. In Braziller $v$, Lind, ${ }^{60}$ for example, the defendant, acting under instructions from his attorney, refused to answer thirty-five questions in an oral deposition, and the attorney resisted a suggestion by the examining attorney that the parties obtain an immediate ex parte ruling on the propriety of the questions asked. The court found that the "basis for the objections taken is utterly groundless," 61 and that the failure to obtain an ex parte ruling was "inexcusable." 62 Since the defendant's actions had resulted in "unnecessary and unreasonable expense upon the adverse party," on the defendant's attorney under rule 37(a). ${ }^{64}$

A few cases have arisen under subdivision (b) of rule $37 . .^{65}$ In Austin Theatre $v$. Warner Bros. Pictures, ${ }^{66}$ the court held that costs could be imposed on an attorney for flagrant misbehavior. In this case, the plaintiff's initial failure to answer interrogatories had resulted in a court order directing the plaintiff to furnish the answers. Despite this order, the plaintiff again failed properly to answer the interrogatories. The court, noting that over two years had passed since the interrogatories were first served, imposed the expenses of securing the order on the plaintiff's attorney under rule $37(\mathrm{~b})$.

The few occasions in which the courts have been willing to impose penalties under rule 37 have all involved a high degree of

or his attorney. See Palma v. Lake Waukomis Dev. Co., 48 F.R.D. 366 (W.D. Mo. 1970). Under subdivision (b), however, the court can act to impose sanctions on its own motion, although it is also free to entertain a motion from a party. The procedure in subdivision (d) appears to be similar to that in subdivision (b), although the rule contains some ambiguity. While the text apparently gives the court the power to impose expenses "in lieu of any order or in addition thereto," the rule also states that "the court in which the action is pending on motion may make such orders in regard to the failure...." A reasonable interpretation would be that the court may act on either its own motion or that of a party.

so 32 F.R.D. 367 (S.D.N.Y. 1963).

si Id. at 368 .

2 Id.

s Id.

" Similarly, in Osolin v. S.S. Colorado, 1 Fed. Rules Serv. 2d 599 (N.D. Cal. 1958), the court relied on rule $37(a)$ to impose the costs of an order on an attorney who had objected without "substantial justification" to questions in an oral deposition.

"s See Austin Theatre v. Warner Bros. Picture, 22 F.R.D. 302 (S.D.N.Y. 1958), and Allen v. United States, 16 Fed. Rules Serv. 507 37b.21 (E.D. Pa. 1951). Significantly, there have apparently been no reported cases in which the provisions of subsection (d) have been used to impose expenses on an attorney, although the court in United Sheeplined Clothing Co. v. Artic Fur Cap Corp., 165 F.Supp. 193 (S.D.N.Y. 1958), did impose expenses on an attorney for behavior that would fall under the revised subdivision (d).

" 22 F.R.D. 302 (S.D.N.Y. 1958). 
culpability. In Braziller, for example, the court held that the "groundless" objections of an attorney "were obviously intended to delay the deposition and to cause additional burden and expense to the opposing counsel." 67 Other cases have taken a similar approach to the type of misconduct that will warrant the invocation of a rule 37 sanction. $^{68}$

The language of rule 37 suggests that the judicial interpretation is unduly narrow. Prior to the 1970 revision of the rule, expenses could be imposed personally on attorneys only if an order to compel discovery had been issued. The rule contained no counterpart to the attorney sanctions presently contained in subsections (b) and (d). Congress not only added these two provisions, but also changed the language of subsection (a) from imposing expenses "if . . the motion was made without substantial justification,"69 to make it appropriate to levy costs "unless" there was substantial justification for the party's actions. The Advisory Committee's Notes to this section explain that "the change in language is intended to encourage judges to be more alert to abuses occurring in the discovery process." The committee defended the revisions by noting that "the present provision of Rule $37(\mathrm{a})$. . . has been little used. . . . It appears that the courts do not utilize the most important available sanction to deter abusive resort to the judiciary." The newly written award-of-expenses provision of subsection (b) "conforms to the changed provision as to expenses in Rule 37(a), and is particularly appropriate when a court order is disobeyed." 72 A further indication of the intended scope of rule 37 lies in the fact that the 1970 revision deleted the word "willful" from the text of subdivision (d). Significantly, the Advisory Committee Notes state that "even a negligent failure should come within Rule $37(\mathrm{~d}) .{ }^{\prime} 73$

6732 F.R.D. 367,368 (S.D.N.Y. 1963).

${ }_{6 x}$ See, e.g., Palma v. Lake Waukomis Dev. Corp., 48 F.R.D. 366, 368 (W.D. Mo. 1970) (costs imposed on attorney under rule 37(a) because "the objections were without foundation and were calculated only to delay the deposition and to cause additional burden and expense to the opposing counsel"); cf. Barter v. Eastern S.S. Lines, Inc., 1 F.R.D. 65 (S.D.N.Y. 1939) (suggesting that proper standard for imposing liability under rule 37 is the presence of "bad faith"); Humphrey's Exterminating Co. v. Poulter, 62 F.R.D. 392, 395 (D. Md. 1974) (suggesting that expenses shold be awarded against an attorney only if discovery was impeded "principally at the [attorney's] instigation").

${ }_{69}$ FED. R. CIv. P. 37(a)(4). The rule originally imposed expenses when a motion was granted "if ... the refusal [of a deponent to answer questions] was without substantial justification." This was also changed to impose expenses "unless" there was substantial justification for the party's actions.

7048 F.R.D. $485,539$.

"Id. at 540 .

${ }^{72}$ Id. at $540-41$.

${ }^{73}$ Id. at $541-42$. 
The language of the rule itself lends support to the view that a minimum degree of culpability, including negligence, should suffice for attorney liability. In subdivision (a)(4), for example, the rule states that "the court shall . . . require . . . the party or attorney ... to pay ... unless the court finds that the opposition to the motion was substantially justified or that other circumstances make an award of expenses unjust." 74 The clear command of the rule is that the award of expenses is mandatory unless some mitigating factor is present..$^{75}$ The current restrictive interpretation of rule 37 is inconsistent with both the language and intent of the rule. Unlike contempt, and perhaps section 1927, rule 37 is not hampered by a strict statutory mens rea requirement. Although it is limited to attorney misconduct occurring during discovery, a broader and more frequent use of rule 37 could substantially alleviate the problem of attorney misconduct.

\section{The Rulemaking Power of the Federal and State Courts}

It is generally recognized that courts possess an inherent power to establish reasonable rules to govern proceedings within their jurisdictions. In 1864, the Supreme Court stated that "all . . Federal courts . . . have authority to make and establish all necessary rules for the orderly conducting business [sic] in the said courts, provided such rules are not repugnant to the laws of the United States." 76 The power to promulgate rules is codified in section 2071 of Title 28 of the United States Code, ${ }^{77}$ as well as in rule 83 of the Federal Rules of Civil Procedure. ${ }^{78}$ The state courts also have such

"F FED. R. Crv. P. 37(a). Similarly, when a motion is denied under rule 37(a)(4), "the court shall ... require ... the party or attorney ... to pay ... unless the court finds that the making of the motion was substantially justified or that other circumstances make an award of expenses unjust" (emphasis added). Fed. R. Crv. P. 37(a)(4).

75 See Palma v. Lake Waukomis Dev. Co., 48 F.R.D. 366, 369 (W.D. Mo. 1970), where the court italicized the phrase "the court shall require" in its discussion of the rule and stated: "[T]hat rule imposes a mandatory duty upon the Court to impose the sanctions therein provided." See also Shapiro v. Freeman, 38 F.R.D. 308, 312 (S.D.N.Y. 1965), where in the context of sanctioning an attorney under rule 37 the court stated that "the Federal Rules of Civil Procedure were designed as an affirmative aid to substantive justice, and those who choose to read them restrictively do so at their peril."

"Heckers v. Fowler, 69 U.S. (2 Wall.) 123, 128 (1864).

77 The Supreme Court and all courts established by Act of Congress may from time to time prescribe rules for the conduct of their business. Such rules shall be consistent with Acts of Congress and rules of practice and procedure prescribed by the Supreme Court.

28 U.S.C. $\$ 2071$ (1970).

78 FED. R. Crv. P. 83 states in part: "Each district court by action of a majority of the judges thereof may from time to time make and amend rules governing its practice not inconsistent with these rules. ... In all cases not provided for by rule, the district courts may regulate their practice in any manner not inconsistent with these rules." 
authority; as the Ohio Supreme Court noted recently, "It is of course fundamental that courts are vested with inherent power to establish rules for regulating their proceedings and for facilitating the administration of justice." ${ }^{\prime 79}$

Acting pursuant to section 2071 and rule 83, in 1961 the Southern District of New York promulgated rule 16(c). This rule provides, in part, that "[i]f counsel fails to comply with any of the Calendar. Rules ... . [the court may] assess reasonable costs directly against counsel whose actions has [sic] obstructed the effective administration of the court's business." 80 The operation of this rule is demonstrated in Schneider $v$. American Export Lines, Inc., ${ }^{81}$ where the plaintiff's action was dismissed for want of prosecution due to the absence of the plaintiff and key witnesses. The plaintiff's attorney, who had been repeatedly notified by the clerk of the court as to the status of the case, was responsible for the absence. The court relied on calendar rule 16(c), rather than on an inherent power, to require the responsible attorney to pay costs to the defendant. ${ }^{82}$

The Second Circuit recently relied on Schneider in the case of In re Sutter, ${ }^{83}$ where costs were imposed on an attorney pursuant to rule $8(\mathrm{~b})$ of the Eastern District Calendar Rules. ${ }^{84}$ While Sutter, an attorney who assumed conflicting trial obligations, was honoring one of his responsibilities, the court with jurisdiction over the other trial invoked rule $8(\mathrm{~b})$ to impose on him costs of five hundred dollars for every day that the trial was delayed. These costs, which covered a three-day delay, were to be paid to the court rather than to the opposing party. In affirming the sanction, the Second Circuit

7 Meyer v. Brinsky, 129 Ohio St. 371, 373, 195 N.E. 702, 703 (1935), cited in Glimcher

v. Doppelt, 5 Ohio App. 2d 269, 215 N.E.2d 423 (1966).

so The full text of rule $16(\mathrm{c})$ reads as follows:

In the sound discretion of any judge of this court, one or more of the following sanctions may be imposed for failure to comply with the Calendar Rules:

(c) Imposition of Costs on Attorneys. If counsel fails to comply with any of the Calendar Rules and the judge finds that the sanctions in sections (a) and (b) above are either inadequate or unjust to the parties in light of the facts or circumstances, he may, in addition to, or in lieu of, such sanctions assess reasonable costs directly against counsel whose actions has [sic] obstructed the effective administration of the court's business. 11 293 F. Supp. 117 (S.D.N.Y. 1968).

2 Rule 16(c) was repealed in 1972. In re Sutter, 543 F.2d 1030, 1037 (2d Cir. 1976).

53 F.2d 1030 (2d Cir. 1976).

s Rule 8 of the Individual Assignment and Calendar Rules for the Eastern District of New York provides:

Rule 8. Sanctions. . . . (b) Imposition of costs on attorneys. If counsel fails to comply with Rules $3(\mathrm{f}), 6(\mathrm{f})$ or 7 or a judge finds that the sanctions in subdivision (a) are either inadequate or unjust to the parties, he may assess reasonable costs directly against counsel whose action has obstructed the effective administration of the court's business. 
explicitly recognized that the court rule prohibited a broader range of attorney misbehavior than that encompassed by contempt. A lesser degree of mens rea was required since "Rule 8 cannot be read so as to require the same finding of willful intent required by the contempt statute. Such a reading would render the rule superfluous." 85

Although some court rules providing for sanctions against attorneys exist on the state ${ }^{86}$ as well as the federal levels, most jurisdictions lack such rules. ${ }^{87}$ The reluctance of most jurisdictions to adopt court rules may be attributable to doubt as to their validity. In Gamble v. Pope \& Talbot, Inc., ${ }^{88}$ an attorney negligently failed to file a pretrial memorandum within the required thirty days, thereby violating a local standing rule of the United States District Court for the Eastern District of Pennsylvania. Pursuant to another "standing order," to be "nonintentional" and hence noncontemptuous but nevertheless imposed a fine of one hundred dollars, payable to the United States, for the wasted court time. ${ }^{80}$ The Third Circuit reversed the imposition of costs on the ground that "the district court has not been given authority and possesses no inherent power to fine an attorney who has not been held in contempt nor given a hearing."'91

This reasoning is of dubious validity. The Second Circuit has expressly rejected the Gamble holding, stating that a court rule is valid as long as it is "not inconsistent with a statute or other rule or the Constitution." "92 The vigorous dissents in the Gamble decision

* In re Sutter, 543 F.2d 1030, 1035 (2d Cir. 1976).

* Court rules imposing costs on attorneys are also promulgated by state courts. In California, for example, rules 26(a) and 135(a) of the California Rules of Court authorize the imposition of costs on attorneys responsible for "frivolous" appeals. There appears to be only one reported case, however, in which these sanctions have been involved. In re Marriage of Milch, 47 Cal. App. 3d 666, 120 Cal. Rptr. 901 (1975). It is possible, however, that these court rules have been utilized in unreported cases.

" See, e.g., U.S. Dist. Ct. Rules, N. J.; U.S. Dist. Ct. Rules, D. C.

307 F.2d 729 (3d Cir.), cert. denied, 371 U.S. 888 (1962).

s" The order states:

For failure to appear at a pre-trial conference, or to participate therein, or to prepare therefore, the Court, in its discretion, may make such order with respect to the imposition of fines, costs and counsel fees, as is just and proper; with respect to the continued prosecution of the cause (complaint, cross-claim or counterclaim), a dismissal may be entered, or as to the defense, the preclusion of all or any part thereof as is likewise just and proper.

Id. at 730 .

* 307 F.2d 729 (3d Cir.), cert. denied, 371 U.S. 888 (1962).

"Id. at 731 .

"In re Sutter, 543 F.2d 1030, 1037 (2d Cir. 1976). The Gamble decision was also criticized in Comment, Dismissal for Failure to Attend a Pre-Trial Conference and the Use of 
itself weaken the precedential authority of the case. One dissent stressed that the majority may have mistakenly construed the trial court's action as if it were a contempt citation rather than a disciplinary action taken under a validly promulgated court rule. ${ }^{93}$ Congress has granted the federal courts the authority to make rules regulating court procedure; no apparent reason exists to limit this power by incorporating the rigid mens rea requirements of contempt. Indeed, the great advantage of sanctions entered pursuant to the courts' rulemaking power is that negligent or reckless conduct can clearly be sufficient for liability. Despite this apparent advantage, however, only a few jurisdictions have enacted court rules, and these jurisdictions use their rules only sporadically ${ }^{94}$ Nevertheless, more jurisdictions may promulgate court rules in the future to take advantage of what may be the most effective sanction against attorney misconduct.

\section{Nonjudicial Sanctions Against Attorneys}

Contempt, section 1927, rule 37, and the inherent rulemaking power of courts are all judicially imposed sanctions levied against attorneys for misconduct occurring during litigation. Attorney misconduct, however, can also be the subject of a separate action brought by a private party or disciplinary proceedings against the attorney in a separate suit.

\section{A. Private Remedies Against Attorneys}

A party who is injured by attorney misconduct can bring a damage action for malicious prosecution, false imprisonment, or abuse of process.

1. Malicious Prosecution. The tort of malicious prosecution consists of four essential elements: ${ }^{85}$ the plaintiff must prove that

Sanctions at Prepatory Stages of Litigation, 72 YALE L.J. 819 (1963).

"3 307 F.2d at 735-37.

" In California, for example, rule 12 of the Northern District Court Rules imposes costs on attorneys, but no reported case involves its application. The rule states:

Failure of counsel, or of a party to comply with these Rules, or amendments thereof, shall be ground for imposition by the Court of appropriate sanctions, including dismissal of a claim or counterclaim under Rule 41(b)(c), Federal Rules of Civil Procedure, or Admiralty Rule 38; entry of default under Rule 55(a); entry of exclusionary orders under Rule 37, Federal Rules of Civil Procedure, or Admiralty Rule 32(c); entry of orders advancing for trial; entry of orders for costs or attorneys' fees under Title 28 U.S.C. Section 1927, or other statute or rule, and other appropriate orders within the power of the Court.

${ }^{9}$ W. Prosser, The Law of Torts $\S 119$ (4th ed. 1971); Durante v. Braun, 263 Md. 685, 284 A.2d 241 (1971). Note that when a cause of action is founded on a civil proceeding, 
the defendant (1) previously instituted either a criminal or a civil proceeding against the plaintiff, which (2) was terminated in favor of the plaintiff, (3) was brought without "probable cause," and (4) with "malice." The courts have uniformly held that if an attorney advances a claim in good faith, he is immune from a suit for malicious prosecution. ${ }^{96}$ But if an attorney has knowledge of his client's wrongful purpose, liability may result. In Burnap v. Marsh, ${ }^{97}$ for example, the defendant attorneys sued out a writ of ne exeat, thereby causing the arrest of the plaintiff, with full awareness that the writ was meritless. The court held that the attorneys were liable for malicious prosecution because they were "morally and legally just as much liable as if [they] were prompted by [their] own malice against the injured party." improper purpose will subject an attorney to liability, the courts are generous in allowing attorneys to rely on the representations their clients make to them as to the true state of facts in a case. ${ }^{99}$

2. False Imprisonment. The tort of false imprisonment, defined as the unlawful restraint by one person of the physical liberty of another, ${ }^{100}$ is so closely related to malicious prosecution that the two are sometimes confused by the courts. ${ }^{101}$ The distinction be-

sometimes called "wrongful civil proceedings," the four elements remain constant. See W. Prosser $§ 120$, at 853-56.

" As one court has stated:

It would be inimical to the administration of justice if an attorney were to be held liable for a malicious prosecution action where, after an honest, industrious search of the authorities, upon facts stated to him by his client, he advises the latter that he has a good cause of action, although the courts upon a trial of such action decide that the attorney's judgment was erroneous. If the issue which the attorney is called upon to decide is fairly debatable, then under his oath of office, he is not only authorized but obligated to present and urge his client's claim upon the court. And if it subsequently is determined that the position honestly taken by the attorney was erroneous he should be relieved from responsibility.

Murdock v. Gerth, 65 Cal. App. 2d 170, 179, 150 P.2d 489, 493 (1944). See also Kassan v. Bledsoe, 252 Cal. App. 2d 810, 60 Cal. Rptr. 799 (1967); Miller v. Metropolitan Life Ins. Co., 28 Ky. L. Rptr. 223, 89 S.W. 183 (1905).

17 Ill, 535 (1852).

" Id. at 538 .

"See, e.g., Maechtlen v. Clapp, 121 Kan. 777, 250 P. 303 (1926) (attorney need not investigate truth of representations made by client); Peck v. Chouteau, 91 Mo. 138, 151, 3 S.W. 577, 581 (1887) ("[t]he attorney has a right to advise and act upon the facts which he gets from his client, and it is not his duty to go elsewhere for information").

100 Reilly v. United States Fidelity \& Guar. Co., 15 F.2d 314 (9th Cir. 1926); Rogers v. Sears, Roebuck \& Co., 48 Wash. $2 d 879,297$ P.2d 250 (1956). The definition of false imprisonment remains the same in cases where its commission is a criminal offense. See, e.g., Parrott v. Bank of America Nat'l Trust \& Sav. Ass'n, 97 Cal. App. 2d 14, 217 P.2d 89, 35 A.L.R.2d 263 (1950); Stephens v. Conley, 48 Mont. 352, 138 P. 189 (1914).

iil See, e.g., Neall v. Hart, 115 Pa. 347, 8 A. 628 (1887); Bolton v. Vellines, 94 Va. 393, 26 N.E. 847 (1897). 
tween them rests on the validity of the authority behind the restraint imposed. In the tort of malicious prosecution, the confinement must be imposed with malice and without probable cause; in false imprisonment, malice and lack of probable cause are not essential since the essence of the tort is the involuntary detention of an individual without valid legal authority. ${ }^{102}$ The defendant need only intend that his act cause the imprisonment of someone or have knowledge that such imprisonment would result. ${ }^{103}$

The courts are split, however, on whether these elements are sufficient to impose liability on an attorney for false imprisonment. The majority rule, as stated by the New York Court of Appeals in Vernes $v$. Phillips, ${ }^{104}$ is that an attorney is liable on the same basis as any other individual. ${ }^{105}$ Other courts have disregarded the Vernes approach and applied the same "good faith" standard that applies to attorneys sued for malicious prosecution. ${ }^{106}$

3. Abuse of Process. Actions for malicious prosecution and false imprisonment provide no remedy for cases in which legal procedures have been properly set in motion, with probable cause, but to accomplish an ulterior, improper purpose. The tort of abuse of process, sometimes termed "malicious abuse of process," 107 covers such situations. Unlike malicious prosecution, "the gist of the tort [of abuse of process] is not commencing an action or causing process to issue without justification, but misusing, or misapplying process justified in itself for an end other than that which it was designed to accomplish."108 In order to sustain a cause of action for abuse of process, the plaintiff must show that the defendant made an improper, illegal, or perverted use of the process with an ulterior motive or purpose..$^{109}$

Attorneys enjoy no immunity from suits for abuse of process. The general rule, as stated in Lambert $v$. Breton,"10 is that "an attorney or agent may be held liable for an abuse of process where the acts complained of are his own personal acts or the acts of others

102 See W. Prosser, supra note 95, at 49, for a comparison of the two actions.

sos See generally W. Prosser, supra note 95, at 48.

tot 266 N.Y. $298,300,194$ N.E. 762,763 (1935). The court stated, "[t]hat he who is responsible is an attorney at law does not change the rule."

${ }^{105}$ Accord, Monson v. Rouse, 86 Mo. App. 97, 102 (1900).

${ }^{106}$ See, e.g., Langen v. Borkowski, 188 Wis. 277, 206 N.W. 181 (1925).

${ }_{107}$ See, e.g., McMullen v. Michigan Home Furnishing Corp., 132 Misc. 338, 230 N.Y.S.

508 (City Ct. N.Y.), aff'd, 133 Misc. 320, 232 N.Y.S. 124 (App. Term 1928).

to W. Prosser, supra note $95, \S 121$.

${ }^{100}$ Id.

110127 Me. 510, 144 A. 864 (1929). 
wholly instigated and carried on by him."'111 In Dishaw $v$. Wadleigh, ${ }^{12}$ for example, the defendant assigned claims to an associate living in another part of the state in order for the associate to institute collection proceedings. The defendant attorney correctly perceived that most debtors would pay the claim rather than submit to the inconvenience of attending a distant court. The court found that the procedure followed by the defendant was entirely legal, but noted that "proceedings that are authorized by law may be made use of for an improper purpose .... The facts here disclose a disreputable method of practice, degrading to an honorable profession and well calculated to bring the administration of justice into reproach and contempt ...."'113 Despite Dishaw and several similar cases, the tort of abuse of process has been of limited effectiveness, asserted successfully against attorneys only in rare cases of extreme misconduct.

\section{B. Bar Disciplinary Proceedings}

The most drastic sanction that can be imposed on an attorney for abusing the legal process is disbarment-revoking the attorney's license to practice law. Any court possessing power to admit attorneys to practice law in a particular jurisdiction has a corresponding power to censure, suspend, or disbar an attorney from practicing in that jurisdiction. ${ }^{114}$ Many jurisdictions have enacted statutes that regulate this power. ${ }^{115}$ Disbarment proceedings are typically initiated by local bar associations, who submit their findings to a court for judicial determination. ${ }^{116}$ However, any interested person or organization-including the court itself-may institute proceedings for the suspension or disbarment of an attorney when his behavior has demonstrated that he is unworthy of continuing as an officer of the court. ${ }^{117}$

In instituting disciplinary actions against attorneys, state bar

III Id. at $515,144 \mathrm{~A}$. at 866 .

11215 App. Div. 205, 44 N.Y.S. 207 (1897).

"Is Id. at 299, 44 N.Y.S. at 208. See also Hoppe v. Klapperich, 224 Minn. 224, 28 N.W.2d 780 (1947).

'1" Ex parte Robinson, 86 U.S. (19 Wall.) 505 (1873); Mullen v. Canfield, 105 F.2d 47 (D.C. Cir. 1939); Beamer v. Waddell, 221 Ind. 232, 45 N.E.2d 1020 (1943).

is E.g., CAl. Bus. \& Prof. Code $\$ \S 6100-6117$ (West 1974); N.Y. Jud. LAw $\S 90$ (McKinney 1968).

i' E.g., Cleveland Bar Ass'n v. Fleck, 172 Ohio St. 467, 178 N.E.2d 782 (1961), cert. denied, 369 U.S. 861 (1962); In re Phillips, 17 Cal. 2d 55, 109 P.2d 344 (1941); In re Pate, 107 S.W.2d 157 (Mo. Ct. App. 1937).

17 Wilbur v. Howard, 70 F. Supp. 930 (E.D. Ky. 1947), rev'd on other grounds, 166 F.2d 884 (6th Cir. 1942); State v. Peck, 88 Conn. 447, 91 A. 274 (1914). 
associations usually rely on local canons of ethics. These canons of ethics are not binding on the courts unless they have been enacted into law. For example, the recently revised Code of Professional Responsibility of the American Bar Association does not bind the courts in specific instances of misconduct, even where the state bar association has adopted it. ${ }^{118}$ Nevertheless, the Code does provide a useful guide as to the types of conduct that will be a basis for sanctions by local bar associations. ${ }^{119}$

\section{ConcLusion}

This comment has explored various sanctions that could be used to regulate attorney misconduct. Section 1927, rule 37 of the Federal Rules of Civil Procedure, and the inherent power of the courts to promulgate rules governing proceedings within their jurisdictions are all potentially useful complements to the contempt sanction. Greater use of these sanctions could provide an effective deterrent against attorneys who abuse the judicial process, and a means to recover the costs caused by their misconduct.

David W. Pollak

118 In re Blatt, 42 N.J. 522, 201 A.2d 715 (1964); People ex rel. Chicago Bar Ass'n v. McCallum, 341 Ill. 578, 173 N.E. 827 (1930).

119 The Code makes no attempt to prescribe either disciplinary procedures or penalties for violation of a Disciplinary Rule, nor does it undertake to define standards for civil liability of lawyers for professional conduct. The severity of judgment against one found guilty of violating a Disciplinary Rule should be determined by the character of the offense and the attendent circumstances.

Preliminary Statement, ABA Code of Professional ResponsiBIITY.

DR 2-109, for example, prohibits a lawyer from accepting employment "on behalf of a person if he knows or it is obvious that such person wishes to: (1) Bring a legal action, conduct a defense, or assert a position in litigation, or otherwise have steps taken for him, merely for the purpose of harassing or maliciously injuring any person." See also DR 1-102 (defining "misconduct" as the violation of a Disciplinary Rule, the circumvention of a Disciplinary Rule through actions of another; and illegal conduct involving moral turpitude); DR 2-110 (requiring an attorney to withdraw from employment if "[h]e knows or it is obvious that his client is bringing the legal action, conducting the defense, or asserting a position in the litigation, or is otherwise having steps taken for him, merely for the purpose of harassing or maliciously injuring any person"); DR 7-102 (requiring a lawyer not to "[f]ile a suit, assert a position, conduct a defense, delay a trial, or take other action on behalf of his client when he knows or when it is obvious that such action would serve merely to harass or maliciously injure another').

For a thorough examination of the relevant canons and Disciplinary Rules, see Symposium, The American Bar Association Code of Professional Responsibility, 48 TEx. L. Rev. 255 (1970); Cady, Canons to the Code of Professional Responsibility, 2 ConN. L. Rev. 222 (196970). 